\title{
An Investigation into the Academic Success of Prospective Teachers in Terms of Learning Strategies, Learning Styles and the Locus of Control
}

\author{
Figen $\mathrm{Akça}^{1}$ \\ ${ }^{1}$ Faculty of Education, Aksaray University, Aksaray, Turkey \\ Correspondence: Figen Akça, Faculty of Education, Aksaray University, Central Campus, Aksaray, Turkey. Tel: \\ 95-535-448-4385. E-mail: figen_akca@hotmail.com
}

Received: August 30, 2012

Accepted: October 19, $2012 \quad$ Online Published: January 16, 2013

doi:10.5539/jel.v2n1p134

URL: http://dx.doi.org/10.5539/jel.v2n1p134

\begin{abstract}
The present research aims to investigate the relationship between the learning strategies, learning styles, the locus of control and the academic success of prospective teachers. The study group consists of 198 university students in various departments at the Uludağ University Faculty of Education. Research data were collected with the Locus of Control Scale (Dağ, 1991), the Determining Learning Strategies Scale (Güven 2008), and the Kolb Learning Style Inventory (Aşkar \& Akkoyunlu 1993). The obtained data were tested with T-test, Pearson product-moment correlation, and multiple regression analysis in independent samples. According to the research results, it was found that the learning strategies usage rates of prospective teachers increased in direct proportion to their academic success, and there was a positive significant relation between the usage of rehearsal learning strategies and being externally controlled. Furthermore, it was determined that learning strategies have predictor effects on academic success in learning styles.
\end{abstract}

Keywords: learning styles, locus of control, learning strategies, academic success

\section{Introduction}

How individuals learn and become more active in the learning process continues to be emphasized in much research. Research reveals that everyone's learning process is different. Some people learn by feeling, some by watching, some by thinking, and others by doing (McCarthy, 1990). Learning is in general explained though two approaches: the behaviorist approach and the cognitive one (Şimşek, 2004). In the cognitive approach, learning is achieved through mental processes and differs from the behavioral approach in which learning is achieved through visible behaviors (Anderson, 1995). The information processing approach, of which explains learning as the cognitive learning process does also refers to learning styles of the individuals. Learning style is defined as the the individual characteristics of the students in relation to affective and physical behaviors involved in learning, taking in knowledge, interacting with knowledge, and responses to knowledge (Felder \& Brent, 2005). The learning style is a concept that does not change over a lifetime but it does change the life of the individual (Kaplan \& Kies, 1995).

The learning style concept was first mentioned in 1960 by Rita Dunn, pioneereing various studies concerning the learning diversity of individuals (Şimşek, 2004). Dunn and Dunn (1993) state that a "learning style" differentiates individuals, it begins with the individual's focus on new and difficult knowledge, and how the knowledge is retained. One of the leading classifications was called the "experiential learning theory" and was developed by Kolb (1984). Within the context of this theory, Kolb tried to explain how individuals approach events, facts, and viewpoints, and how they solve problems. In experiential learning theory, the learning was designed on a learning cycle and four learning styles were described in this cycle. These learning styles are concrete experience reflective observation, abstract conceptualization, and active experimentation. In each learning style, there are different learning paths. Concrete experience is based on "feeling and touching", reflective observation is based on "watching and listening", abstract conceptualization is based on "thinking", and active experimentation is based on learning by "doing". In this model, which was developed in terms of learning preferences, there are four types of learning styles; diverging, converging, assimilating, and accommodating (Kolb, 1984; Şimşek, 2004). 
In the light of the studies conducted on learning to learn, two concepts emerged; "learning style", which includes the learning skills of individuals, and the "learning strategy", which includes the techniques that are used in learning (Güven, 2004; Şimşek, 2004). As mentioned above, while a learning style is considered to be a fixed characteristic of the individual, the learning strategy concept means the change is related to situations and tasks. Learning strategy predominantly includes the approaches that are learned in the social environment and developed to cope with certain situations. Learning strategies can be considered to be the methods followed when learning styles are not ideal and do not work (Riding \& Cheema 1991, as cited by Şimşek, 2004). Learning strategies are important parts of the learning process. These offer significant clues to the educator for utilization in education at the highest level (Schunk, 2009).

In general, learning strategies include storage allocation, recalling, and directive and executive cognitive processes. The behavioral and thinking processes, which affect the learning of individuals and used by individuals, are also referred to in the literature (Arends, 1977). According to Wittrock (1986), learning strategies include the techniques that allow the individual to transfer stimulations (right word - check?) to short-term and long-term memory, and to store them in the long-term memory while learning. These strategies, ones that ease learning, motivate students and allow the new behaviors to become permanent. Schunk and Zimmerman (2003) suggest that learning strategies encourage the activities of selecting and organizing knowledge, the relating of new knowledge to stored knowledge, the examination of the learning material, an increase in the meaningfulness of the materials, and the protection of a meaningful learning climate. The essential function of learning strategies is to allow the students to control and direct their learning.

In learning different strategies, at school and in the outside world, a trial-and-error method and taking clues from the immediate environment are of importance (Senemoğlu, 2010; Orhan, F. 2008). Learning strategies from sources such as books, magazines, friends and parents play a less important role. It can be said that some students, using different learning styles and developing new learning strategies, can realize effective learning on their own (Adderley, 1987). It is also important to recognize which strategy will be appropriate to use in different situations. Therefore, the main purpose of teaching learning strategies is to enable the students to control their own learning (Senemoğlu, 2010). This can be possible only if we can efficiently teach students how learning strategies should be used. (Adderley, 1987). According to Mayer (1987), there are three development stages. The first, which is also called preschool, is the early stage; no learning strategy is achieved and used by the learner. The second stage is the transition stage that includes the first grade of primary education where the children mostly mimic the external learning strategies used by the adults. The final stage starts in the second grade of primary education and extends to adulthood when students organize their own learning strategies (Oxford \& Ehrman, 1995). According to Mayer (1987), teachers and study habits are crucial to the development of the learning strategies of secondary school students.

Various classifications related to learning strategies were found in the literature. Gagné (1988) explained learning strategies by considering learning processes in accordance with knowledge processing theory and classified them into five groups: attention, short-term storing, coding, recalling, and watching strategies. In the learning model developed by Weinstein and Mayer (1986), the elements of the learning process were gathered under four stages: selection (transferring the stimulants to short term memory), gain (transferring from processor memory to long-term memory), structuring (interpreting the knowledge), and integrating (relating the stored knowledge to new knowledge). According to this model (Weinstein \& Mayer, 1986), learning strategies in general are classified as elaboration, comprehension-following, organization, affective, and rehearsal strategies.

In elaboration strategies, students integrate new knowledge with previously acquired knowledge, knowledge that exists in their long term memories, and attribute fresh meanings to the old knowledge. Elaboration is a detail-adding process to make a new information more meaningful (Özer, 1998). Comprehension-monitoring strategies are based on devising activities for the students to perform. These strategies help students to determine, conduct, and control their own learning skills (Senemoğlu, 2010). Organization strategies are the strategies that increase the elaboration levels of the students for assimilating new material. These strategies allow new material to be re-structured, re-organized and interpreted. In learning, the strategies helping to remove the barriers are called affective strategies (Senemoğlu, 2010). According to Weinstein and Mayer (1986), the main rehearsal strategies include reciting and naming the lesson content. These strategies are effective for understanding the course materials as presented in class.

In an effective learning process, an individual should be active and strategic, able to correlate the materials and develop collaborative skills and aims to meet course aims (Watkins et al., 2000). The combined application of learning styles and strategies is important for upgrading the success levels of students and for them to be aware of their own cognitive processes (Nisbet \& Shucksmith, 1986). According to recent studies, if these two concept 
are used together, they effect learning outputs (Tinajero \& Paramo, 1998; Halaçoğlu, 1999; Sadler-Smith, 1997; Ocak \& Yamaç, 2011; Keane, 1993; Oxford et al., 1993). Studies concerned with different application of these concepts in different situations are rare (Güven, 2004).

Numerous studies conducted on the usage of learning strategies and academic successes have demonstrated that there is a strong relation between the used strategy and academic success (Seigler, 1991; Sünbül, 1998; Jonassen \& Grobowski; 1999). If students are taught learning strategies, they become more successful and exhibit better motivation (Bulut, 2006; Jonassen \& Grobowski, 1999).

The locus of control is an important variable in explaining the behaviors of students in the education environment (Öngen, 2003). Internally controlled people believe that their success is strongly dependent on their own efforts and skills, whereas others believe in destiny, fortune and power. There is also a relation between learning modes and the locus of control. Thus, it is seen that internally controlled people have more active and proper learning modes. However, those more externally focused condemn themselves to failure through inadequate and improper study skills (Cassidy \& Eachus, 2000; Nelson \& Mathia, 1995).

However, it has been proved that internal and external controls have an effect on the levels of success in academic achievement (Bar-Tal \& Bar-Zahor, 1977; Cassidy \& Eachus, 2000; Lefcourt, 1992). The overall result of the studies conducted on the relation between the locus of control and academic success is that while there is positive relation between internal control and academic success, there is a negative relation between external control and academic success (Fayeke, 2011; Swanson, 1980; Yeşilyaprak, 2004).

Ocak and Yamaç (2011) investigated the relation between learning strategies, the locus of control, and success in their studies using structural equality modelling. According to the research results, while the locus of control has not a significant effect on explaining success, learning strategies have a significant effect on explaining success. Because the studies related to locus of control were generally conducted in clinic environments, they were not found to be useful for the conditions that effect learning and teaching. However, the number of the studies on this subject has gradually increased.

\subsection{The Purpose of the Research and the Problem}

In learning environments, generally, the individual learning differences of students are considered, but all students are offered the same time, the same mode, and the same learning possibilities, and they are expected to achieve the same goals. But individual difference is an important factor that presents problems for both the learner and the teacher (Şimşek, 2004). Thus, an awareness of learning styles, learning strategies and the locus of control and their roles in academic success is of a great importance for educational psychologists, teachers and researchers.

The aim of the present research is to reveal the relation between learning strategies, learning styles, the locus of control, and the success of prospective teachers, and to bring forward proposals on the learning process. Accordingly, the following questions are asked:

1) What are the learning styles that prospective teachers use, is there any relation between their academic success, learning strategies and the locus of control?

2) Do the learning strategies of prospective teachers predict their academic success at a significant level?

3) Do the learning strategies and learning styles of prospective teachers predict their academic success at a significant level?

4) Is there a significant relation between the learning strategies used by prospective teachers and their genders?

5) Do the learning strategies used by prospective teachers differ significantly according to their departments?

Answers to these questions will be sought.

\section{Method}

In this research, which aims to determine the relation between academic success, the learning styles, and the locus of control of prospective teachers who study in the Uludağ University Education Faculty, singular and relational screening models (Karasar, 1998) were used. A singular seeking model was used to determine academic success, learning styles, learning strategies, and the locus of control. A relational scanning model was used to determine the relation between academic success, learning styles, learning strategies, and the locus of control. For this purpose, data that were obtained from the scale applied to the students were related with each other. 


\subsection{Participant (Subject) Characteristics}

The study group consisted of 198 volunteers aged between 19 and 25 years (aged mean 21.02, 138 students are female and 60 students are male) who were studying at the Uludağ University Education Faculty in the 2011-2012 academic year. Each set of data was separately collected from each class and 20 minutes were allocated to each student for completing each scale. However, a sample group was formed because of the largeness of the universe. In forming the sample, a proportional cluster sampling approach (Karasar, 1998) was used. Ten percent of the students were considered and volunteers in this group participated in the study. The distribution of the prospective teachers who formed the sample in terms of personal characterisitics are shown in Table 1.

Table 1. The distribution of prospective teachers who form the sample in terms of personal characteristics

\begin{tabular}{llll}
\hline Variables & & $\mathrm{n}$ & $\%$ \\
\hline \multirow{3}{*}{ Gender } & Female & 138 & 69.7 \\
& Male & 60 & 30.3 \\
& Total & 198 & 100.0 \\
& General High School & 51 & 25.8 \\
Graduated High & Anatolian High School & Vocational High School & 36.4 \\
School Type & Anatolian Teacher High School & 18 & 9.1 \\
& Religious Vocational High School & 16 & 8.1 \\
& Other & 18 & 9.1 \\
& Total & 19 & 9.6 \\
& Primary School Teaching & 198 & 100.0 \\
& Mathematics Teaching & 28 & 14.1 \\
& Guidance and Counselling Teaching & 16 & 8.1 \\
& Social Science Teaching & 31 & 15.7 \\
& Science Teaching & 12 & 6.1 \\
& Language Teaching & 21 & 10.6 \\
& Pre-School Teaching & 30 & 15.2 \\
& Religion And Ethics Teaching & 38 & 19.2 \\
& Total & 22 & 11.1 \\
& $2^{\text {nd }}$ Grade & 198 & 100.0 \\
& $3^{\text {rd }}$ Grade & 30 & 15.2 \\
& $4^{\text {th }}$ Grade & 92 & 46.5 \\
& Total & 76 & 38.4 \\
& & 198 & 100.0 \\
\hline
\end{tabular}

\subsection{Research Instruments}

For the purposes of the research, the "Kolb Learning Style Inventory", "Learning Styles Determining Scale", the Rotterdam Control Scale and a "Personal Information Sheet" were used in order to gather data.

\subsubsection{The Learning Strategies Determining Scale}

"Learning Strategies Scale" was used in order to determine learning strategies. Learning Strategies Scale was developed on the basis of the classification of Weinstein and Mayer (1986) by Güven (2008). The validity and reliability test of the scale was conducted by the researcher and the internal reliability coefficient was found to be.87. The Learning Strategies Scale consists of five sub-dimension, 35 items, and participants indicated the degree to which they agree with each item on the scale using a five point Likert-type scale. The item-total 
correlations ranged from .43 and .74 . The internal consistency coefficients were .81 for elaboration strategy .79 for comprehension-monitoring strategy, .76 for organization strategy, .70 for affective strategy, and .61 for rehearsal strategy.

\subsubsection{The Kolb Learning Style Inventory}

The Learning Style Inventory was used. The Learning Style Inventory was developed in 1984 in order to determine learning styles by Kolb. Kolb Learning Style Model, which was adapted to Turkish by Aşkar and Akkoyunlu (1993) includes four learning styles. The inventory consists of 12 items with four choices . In Kolb's model, the person is required to employ each of the four key learning abilities: concrete experience (CE), abstract conceptualization (AC), reflective observation (RO), and active experience (AE) (Kolb, 1984). The form of learning styles is a combination of four learning abilities: CE, AC, RO, and AE (Kolb, 2005). According to Kolb, there are four fundamental learning styles. The diverging learning style specializes in the two learning abilities of CE and RO. In contrast, the converging learning style specializes in the two abilities of AC and AE. The assimilating learning style specializes in the two abilities of AC and RO. By contrast, finally, the accommodating learning style specializes in the two abilities of CE and AE. Notably, both converging and assimilating learning styles have a higher score in abstract conceptualization (AC) and lower score in concrete experience (CE). Abstract conceptualization which is actualized in adolescence is conceived to be a higher level ability compared with concrete experience (CE) (Kolb, 1984; Jonnassen \& and Grobowski, 1999; Damavandi et al., 2011). The internal consistency coefficients were calculated as .58 for concrete experience, .70 for reflective observation, .71 for abstract conceptualization, .65 for active experience, .65 for abstract-concrete, and .76 for reflective observation.

\subsubsection{Locus of Control Scale}

In the study, "Internal and External Locus of Control Scale", which was developed by Rotter and adapted to Turkish by Dağ (1991) was used to determine the locus of control of the students. The scale consists of 29 items, 6 of them are filler items. The possible range of scores is from 0 to 23. If the scores increase, the individual is externally controlled and if the scores decrease, the individual is internally controlled. For the total scale, the internal reliability coefficient was calculated as 0.71 .

\subsubsection{Personal Information Sheet}

In this form, there were questions related to the departments, gender, grades, and grade-point averages of the students.

\subsection{Analysis of and Comment on the Data}

The data that were obtained from the scales used in the research were transferred to a computer environment and analyzed using SPSS for Windows version 20. The data obtained were tested with t-test, Pearson product moment correlation, and multiple regression analysis in independent samples.

\section{Results}

In this section, the findings and explanations based on these findings are given.

\subsection{What Are Frequencies of Learning Styles in Prospective Teachers?}

Table 2. The frequency of learning styles used by prospective teachers

\begin{tabular}{llll}
\hline Variables & & $\mathrm{n}$ & $\%$ \\
\hline \multirow{3}{*}{ Learning style } & Accommodating Learning Style & 31 & 15.7 \\
& Diverging Learning Style & 64 & 32.3 \\
& Assimilating Learning Style & 64 & 32.3 \\
& Converging Learning Style & 39 & 19.7 \\
& Total & 198 & 100.0 \\
\hline
\end{tabular}

As was seen in Table 2, the distribution of the learning styles of prospective teachers is considerably homogenous. It is seen that students use diverging and assimilating learning styles equally (32.3\%) but they use less converging and accommodating learning styles. 


\subsection{What Are Means and Standart Deviations of Learning Strategies in Prospective Teacher?}

Table 3. The learning strategies of prospective teachers, mean and standard deviations

\begin{tabular}{lllll}
\hline & & (Mean) & (SD) & (n) \\
\hline \multirow{3}{*}{ Learning Strategies } & Rehearsal & $\mathbf{3 . 8 4}$ & $\mathbf{. 6 8}$ & $\mathbf{1 9 8}$ \\
& Elaboration & $\mathbf{3 . 8 7}$ & $\mathbf{. 5 7}$ & $\mathbf{1 9 8}$ \\
& Organization & 3.67 & $\mathbf{. 7 1}$ & $\mathbf{1 9 8}$ \\
& Comprehension-monitoring & 3.81 & .55 & $\mathbf{1 9 8}$ \\
& Affective & 3.92 & .61 & $\mathbf{1 9 8}$ \\
\hline
\end{tabular}

*Highest score 5

According to the results of the analysis that was conducted on the learning styles of the students, the mean of elaboration strategy is $\mathbf{3 . 8 7}$, the mean of comprehension-monitoring strategy is $\mathbf{3 . 8 1}$, the mean of organization strategy is $\mathbf{3 . 6 7}$, the mean of affective strategy is $\mathbf{3 . 9 2}$, and the mean of rehearsal strategy is $\mathbf{3 . 8 4}$. On the basis of these data, it is seen that prospective teachers generally use all learning styles, their most preferred learning strategy is affective strategy, and the least preferred strategy is organization strategy.

3.3 Relations among Academic Success, Learning Strategies and the Locus of Control

Table 4. Mean and standart deviations and correlations among learning strategies, socus of control, and academic success

\begin{tabular}{|c|c|c|c|c|c|c|c|c|c|}
\hline Variables & (Mean) & $(\mathrm{SD})$ & $\mathrm{I}$ & II & III & IV & $\mathrm{V}$ & VI & VII \\
\hline I. Academic Success & 70.15 & 12.11 & & $.20^{* *}$ & $.29^{* *}$ & $.19^{* *}$ & $.28^{* *}$ & $.29^{* *}$ & .06 \\
\hline II. Rehearsal & 23.01 & 4.10 & & - & $.60^{* *}$ & $.41^{* *}$ & $.66^{* *}$ & $.53^{* *}$ & $.16^{*}$ \\
\hline III. Elaboration & 42.53 & 6.30 & & & - & $.64^{* *}$ & $.76^{* *}$ & $.59^{* *}$ & -.04 \\
\hline IV. Organization & 25.70 & 4.95 & & & & - & $.68^{* *}$ & $.45^{* *}$ & -.05 \\
\hline $\begin{array}{l}\text { V.Comprehension- } \\
\text { monitoring }\end{array}$ & 34.27 & 4.95 & & & & & - & $.66^{* *}$ & .03 \\
\hline VI. Affective & 23.52 & 3.66 & & & & & & - & -.05 \\
\hline VII. Locus of Control & 11.80 & 3.91 & & & & & & & - \\
\hline
\end{tabular}

**p $<.01,{ }^{*} \mathrm{p}<.05$

When Table 4 is examined, it can be seen that rehearsal $(\mathrm{r}=.29, \mathrm{p}<.01)$, elaboration $(\mathrm{r}=.19, \mathrm{p}<.01)$, organization $(\mathrm{r}=.28, \mathrm{p}<.01)$, and comprehension-monitoring $(\mathrm{r}=.29, \mathrm{p}<.01)$ learning strategies related negatively to academic success. Furthermore, it is seen that there is positive relation $(\mathrm{r}=.16, \mathrm{p}<.05)$ between the locus of control and rehearsal strategy. There were also significant correlations between dimensions of learning strategies.

\subsection{Prediction Academic Success by Learning Strategies in Prospective Teachers}

Required assumptions were examined to be met, before hypothesis concerning prediction of academic success by learning strategies and locus of control were tested via multiple regression analysis. Linearity and normality assumptions were examined with histogram and P-P plot, while homoscedasticity was examined using scatter plot. The obtained findings showed that these assumptions were met. In order to determine univariate outliers, standardized $\mathrm{z}$ scores were used and no score was seen out of the range of +4.00 and -4.00 . In order to examine multivariate outliers, Mahalanobis distance values were used and it was seen that the values differ from 1.00 to 1.528. These scores show that there is no multicollinearity. After determining that the required assumptions are met, multiple regression analysis was conducted. The results of the multiple regression analysis can be seen in table 5 . 
Table 5. The results of the multiple regression analysis: predicting academic success from elaboration, affective, rehearsal, organization, comprehension-monitoring learning strategies

\begin{tabular}{ccccc}
\hline Variables & $B$ & Standard Error B & $\beta$ & $\mathrm{t}$ \\
\hline $1^{\text {st }}$ Step & & .131 & .292 & $4.28^{*}$ \\
Elaboration & .562 & & & \\
$2^{\text {st }}$ Step & & .161 & .190 & $2.27^{*}$ \\
Elaboration & .366 & .277 & .173 & $2.07^{*}$ \\
Affective & .574 & .277 & \\
\hline
\end{tabular}

In the first step of the regression analysis, it was seen that elaboration strategy explains $9 \%$ of academic success $\left(R^{2}=.09\right.$, adjusted $\left.R^{2}=.08, F(1,196)=18.32, p<.05\right)$. In the second step, affective strategies also got in the regression equality and contribute explained variance in the level of $2 \%\left(R^{2}=.11, \Delta R^{2}=.02\right.$, adjusted $R^{2}=.10$, $F(1,195)=4.28, p<.05)$. According to beta weights, the relative important variable is elaboration strategy in the prediction of academic success $(\beta=.190)$.

3.5 Prediction Academic Success by Learning Strategies in Prospective Teachers Who Use Different Learning Styles

Table 6. The results of regression analysis on academic success in prospective teachers who use accommodating learning style

\begin{tabular}{cccccc} 
& Variables & $B$ & Standard error & $\beta$ & $\mathrm{t}$ \\
\cline { 2 - 6 }$* \mathrm{p}<.05$ & Rehearsal & 1.102 & .499 & .380 & $2.21^{*}$ \\
\cline { 2 - 6 }
\end{tabular}

The multiple regression analysis showed that the rehearsal learning strategy explains $14 \%$ of academic success in people who use accommodating learning style $\left(R=.14\right.$, adjusted $\left.\mathrm{R}^{2}=.11, F(1,29)=4.88, p<.05\right)$.

Table 7. The results of regression analysis on academic success in prospective teachers who use divergent learning style

\begin{tabular}{ccccc}
\hline Variables & $B$ & Standard error & $\beta$ & $\mathrm{t}$ \\
\hline Elaboration & .543 & .270 & .247 & $2.007^{*}$ \\
\hline
\end{tabular}

$* \mathrm{p}<.05$

The multiple regression analysis showed that the elaboration learning strategy explains $14 \%$ of academic success in people who use divergent learning style $\left(R=.06\right.$, adjusted $\left.\mathrm{R}^{2}=.04, F(1,62)=4.02, p<.05\right)$.

Table 8 . The results of regression analysis on academic success in prospective teachers who use assimilating learning style

\begin{tabular}{ccccc}
\hline Variables & $B$ & Standard error & $\beta$ & $\mathrm{t}$ \\
\hline Affective & 1.299 & .447 & .346 & 2.905 \\
\hline
\end{tabular}

The multiple regression analysis showed that the affective learning strategy explains $12 \%$ of academic success in people who use assimilating learning style $\left(R^{2}=.12\right.$, adjusted $\left.R^{2}=.11, F(1,62)=8.44, p<.05\right)$. 
Table 9. The results of regression analysis on academic success in prospective teachers who use convergent learning style

\begin{tabular}{ccccc}
\hline Variables & $B$ & Standard error & $\beta$ & $\mathrm{t}$ \\
\hline Comprehension-following & .811 & .267 & .447 & 3.038 \\
\hline
\end{tabular}

The multiple regression analysis showed that the affective learning strategy explains $12 \%$ of academic success in people who use assimilating learning style $\left(R^{2}=.20\right.$, adjusted $\left.R^{2}=.18, \mathrm{~F}(1,37)=9.23, p<.05\right)$.

\subsection{Gender Differences in Learning Strategies Used by Prospective Teachers}

The results of the analysis, which was conducted to investigate whether or not the learning strategy usage changes according to gender, are presented in Table 10. Whether or not usage of rehearsal, elaboration, organization, following and affective learning strategies differ according to gender were analyzed through independent samples t-test.

Table 10. The $t$ test results for gender difference in learning strategies

\begin{tabular}{lllllll}
\hline \multirow{2}{*}{ Rehearsal } & Gender & $\mathrm{N}$ & $\mathrm{M}$ & $\mathrm{SD}$ & $\mathrm{t}$ & $\mathrm{P}$ \\
\multirow{4}{*}{ Elaboration } & Male & 60 & 21.83 & 4.52 & 2.71 & $.007^{* *}$ \\
& Female & 138 & 23.52 & 3.81 & & \\
Organization & Male & 60 & 40.66 & 6.56 & 2.79 & $.006^{* *}$ \\
& Female & 138 & 43.34 & 6.02 & & \\
Comprehension-monitoring & Male & 60 & 24.11 & 4.98 & 3.03 & $.003^{* *}$ \\
& Female & 138 & 26.39 & 4.80 & & \\
& Male & 60 & 32.41 & 5.05 & 3.58 & $.000^{* *}$ \\
& Female & 138 & 35.07 & 4.69 & &. \\
& Male & 60 & 22.41 & 3.86 & 2.86 & $.005^{* *}$ \\
& Female & 138 & 24.00 & 3.47 & & \\
\hline
\end{tabular}

$* * \mathrm{p}<.01$

When Table 10 is examined, the usage of rehearsal, elaboration, organization, comprehension-following, and affective strategies differentiates in terms of gender. In this regard, it can be said that females use more rehearsal $(M=23.52)$, elaboration $(M=43.34)$, organization $(M=26.39)$, and comprehension-monitoring strategies when compared with males ( $M=21.83,40.66,24.11,26.39,32.41$, and 22.41, respectively). On the basis of these findings, it can be stated that female students are more strategic learners in the dimensions of rehearsal, elaboration, comprehension-monitoring, organization, rehearsal, and affective strategies.

The differences between prospective teachers in usage of learning strategies according to departments of them

The results of the analysis, which was conducted to investigate whether or not the learning strategy usage changes according to departments, are presented in Table 10. Whether or not usage of rehearsal, elaboration, organization, following and affective learning strategies differ according to gender were analyzed through one-way ANOVA. 
Table 11. The one-way ANOVA results of the prospective teachers' learning strategies according to their departments

\begin{tabular}{|c|c|c|c|c|c|c|}
\hline & $\begin{array}{ll}\text { Source } & \text { Of } \\
\text { Variance } & \end{array}$ & $\begin{array}{l}\text { Sum of } \\
\text { Squares }\end{array}$ & sd & $\begin{array}{l}\text { Mean } \\
\text { Square }\end{array}$ & $\mathrm{F}$ & $\mathrm{p}$ \\
\hline \multirow[t]{3}{*}{ Rehearsal Strategy } & \multirow{2}{*}{$\begin{array}{l}\text { Between } \\
\text { Groups }\end{array}$} & 173.899 & 7 & 24.843 & \multirow[t]{3}{*}{1.501} & \multirow[t]{3}{*}{0.169} \\
\hline & & 3145.056 & 190 & 16.553 & & \\
\hline & $\begin{array}{l}\text { Within } \\
\text { Groups Total }\end{array}$ & 3318.955 & 197 & & & \\
\hline \multirow[t]{3}{*}{ Elaboration Strategy } & \multirow{2}{*}{$\begin{array}{l}\text { Between } \\
\text { Groups }\end{array}$} & 485.182 & 7 & 69.312 & \multirow[t]{3}{*}{1.795} & \multirow[t]{3}{*}{0.090} \\
\hline & & 7336.071 & 190 & 38.611 & & \\
\hline & $\begin{array}{l}\text { Within } \\
\text { Groups Total }\end{array}$ & 7821.253 & 197 & & & \\
\hline \multirow[t]{3}{*}{ Organization Strategy. } & \multirow{2}{*}{$\begin{array}{l}\text { Between } \\
\text { Groups }\end{array}$} & 308.182 & 7 & 44.026 & \multirow[t]{3}{*}{1.844} & \multirow[t]{3}{*}{0.081} \\
\hline & & 4536.828 & 190 & 23.878 & & \\
\hline & $\begin{array}{l}\text { Within } \\
\text { Groups Total }\end{array}$ & 4845.010 & 197 & & & \\
\hline \multirow{3}{*}{$\begin{array}{l}\text { Comprehension-Monitoring } \\
\text { Strategy }\end{array}$} & Between & 233.431 & 7 & 33.347 & \multirow[t]{3}{*}{1.379} & \multirow[t]{3}{*}{0.216} \\
\hline & Groups & 4595.842 & 190 & 24.189 & & \\
\hline & $\begin{array}{l}\text { Within } \\
\text { Groups Total }\end{array}$ & 4829.273 & 197 & & & \\
\hline \multirow[t]{3}{*}{ Affective Strategy } & \multirow{2}{*}{$\begin{array}{l}\text { Between } \\
\text { Groups }\end{array}$} & 73.956 & 7 & 10.565 & \multirow[t]{3}{*}{0.782} & \multirow[t]{3}{*}{0.603} \\
\hline & & 2565.417 & 190 & 13.502 & & \\
\hline & $\begin{array}{l}\text { Within } \\
\text { Groups Total }\end{array}$ & 2639.374 & 197 & & & \\
\hline
\end{tabular}

Departments: Primary School Teaching, Mathematics Teaching, Guidance and Counselling, Social Science Teaching, Science Teaching, Language Teaching, Pre-School Teaching, Religion and Ethics Teaching

The $\mathrm{F}$ values obtained from variance analysis related to usage of rehearsal, elaboration, organization, comprehension monitoring and affective learning strategies were $\mathrm{F}(7,190)=24.84, \mathrm{~F}(7,190)=69.31$, F $(7$, $190)=44.02$, F $(7,190)=33.34$, and $F(7,190)=10$ respectively. These values indicated that there were no significant differences among departments ( $\mathrm{p}>.05)$.

\section{Discussion}

According to the first finding obtained from this study, it is seen that most students use assimilating and converter learning styles more frequently than adaptive and transformative learning styles. This finding parallels the findings in the studies of Güven (2004) and Çağlltay and Tokdemir (2004). Thus, it is seen that most prospective teachers prefer abstract conceptualization and the learning modes requiring mental observation and the others prefer concrete experiences and the learning modes requiring active application. In other words, it is seen that the students with assimilating learning styles generally prefer structured systematic knowledge and do not prefer applicable activities. According to these results, it can be explained why most university students are better at theory but inadequate at practical work.

Another finding obtained from the research is that prospective teachers generally use all learning strategies but the most used strategies are affective strategies and elaboration strategies. It was seen that the least preferred learning strategies are organization strategies. This finding is in parallel with the findings in numerous studies (Güven, 2004; Keane, 1993). Öztürk (1995) states that teachers frequently emphasize rehearsal and affective strategies, they rarely use other strategies in lessons. At this stage, we can say that prospective teachers imitate their teachers at least in terms of using affective strategies.

One of the main purposes of the research was to investigate the relation between academic success, learning strategies, and the locus of control. Reasonable relations were found between all learning strategies and 
academic success and between the locus of control and the rehearsal learning strategy. According to these results, the students use more learning strategies and their academic success increases more. It is seen that this finding coincides with the findings of other studies in the literature investigating the relations between learning strategies and success levels. In some studies, the affects of taking down, rehearsal, elaboration (Akın, 2007), organization (Cebesoy, 2009), and self-regulatory (Haşlaman \& Aşkar, 2007; Zimmerman, 1990) learning strategies on learning were investigated. By contrast, the relation between using more than one strategy and success levels was investigated. According to the regression analysis concerning learning strategies and academic success, the most important variable is the elaboration strategy in predicting academic success.

However, the fact that students using rehearsal learning strategies are also externally controlled students is consistent with the literature. In their study, Cassidy and Eachus (2000) found that while internals are more active in learning and have proper learning modes, the skills of the external are insufficient and improper. As mentioned above, rehearsal strategies require the student to memorize and name the material that was offered to $\mathrm{him} / \mathrm{her}$. This coincides with generalization, oriented to the studies that do not require attention-gathering and dispersed requiring external personal properties. (Yeşilyaprak, 2004). Thus, while internally controlled people are effective in conceptual studies based on synthesizing knowledge and relation and in situations where they can test their personal knowledge and skills; externally controlled people are effective in the duties requiring social interaction, processes based on empathy and relationships with others and in repeated exercises (Yeşilyaprak, 2004).

According to Jonassen and Grabowski (1993), while internally controlled people are effective in strategies such as focusing knowledge, predicting outcomes, cause-effect relations, testing personal skills, and assessing the value and usefulness of knowledge, externally controlled people are effective in strategies such as repeating the subject, illustrating and turning knowledge into symbols, and organizing the mood. Therefore, the fact that internally controlled people and externally controlled people have different learning properties can affect the use of learning strategies. The learning strategies shared by internally and externally controlled people may differ.

One of the most important findings obtained from the present research concerns the regression analysis results about the learning styles, learning strategies, and success-predicting for prospective teachers. According to these results, if the students using an accommodating learning style use a rehearsal strategy; the students using diverging learning style use an elaboration strategy; the students using assimilating learning style use an affective strategy; and the students using affective and converging learning styles use a comprehension-monitoring strategy, then their academic successes are seen to be increased.

These findings are important for seeing the efficiency of using learning styles and learning strategies as a predictor of academic success. Within the framework of this study, the research that could be accessed and is mentioned above investigated the relation between learning styles and learning strategies or the predictive effect of these on academic success. In his study conducted with prospective teachers, Güven (2004) found that students with a transformative learning style generally use comprehension-monitoring strategies more than the students with adaptive and distinctive learning styles. Furthermore, in the same research, it was found that the students with transformative and assimilating learning styles use affective strategies more than the students with adapting and distinctive learning styles. These findings are in parallel with the findings obtained in the present study. There is other research that supports these findings. For example, in their study, Tinajero and Paramo (1998) stated that the students with field-dependent learning styles and the students with field-independent learning styles use different learning strategies. Similarly, in various studies, it was found that there is a positive relation between learning styles and learning strategies and students with different learning styles use different learning strategies (Sadler-Smith, 1997; Liu \& Reed, 1994; Keane, 1993, Oxford et al., 1993; Damavandi, et al., 2011; Karakış, 2006; Kaya, 1995). However, in their studies, Halaçoğlu (1999) and Oxford and Ehrman (1995), stated that there is not a significant relation between learning strategies and learning styles.

Jonassen and Grobowski (1999), attempted to determine the learning strategies that students can use in the light of the studies based on the learning styles suggested by Kolb; the students with distinctive learning styles generally use elaboration, comprehension following and organization strategies. On the other hand, it was found that the students with assimilating learning styles frequently use elaboration and organization learning strategies and the students with transforming learning styles frequently use rehearsal, comprehension-following, and affective learning strategies. The students with adapting learning styles use elaboration, comprehension-following, affective, and organization learning strategies

The final sub-problem of the research was to investigate whether or not the learning strategies used by prospective teachers differed according to gender. According to the findings, females use rehearsal, elaboration, 
affective, organization, and comprehension-monitoring strategies more than males at a significant level. This finding is in parallel with Güven's (2004) study. In this study, it was found that female students used rehearsal strategies, elaborations strategies, comprehension strategies, and affective strategies more than male students; they used organization strategies at a similar intensity to that of male students.

One of the limitations of the present research is the size of the study sample which is restricted solely to students at Uludag University, and the second limitation is the measuring tools which are self-declarative and based on the assumptions of the students. Therefore, students' learning styles, strategies and the locus of control are assumed to be as they are asserted.

The findings of this research and the limitations are evaluated all together and the following is emphasised above. Prospective teachers should be informed about using learning strategies and styles and gain applicable skills (Adderley, 1987; Murray-Harvey, 1994). This demonstrates that subjects like the locus of control and learned helplessness, as well as learning and success variables, should be dealt with. Instructors in all education faculties especially should a) raise the awareness of prospective teachers on using active learning styles and strategies and b) educate the new generation.

\section{References}

Adderley, K. B. V. (1987). The effects of student cognitive style, teacher cognitive style, and instructional method on the achievement of baccalaureate nursing students. Dissertation Abstracts in Humanities and Social Sciences, 47(8A), 29-49.

Akın, Ö. (2007). Anadolu güzel sanatlar liseleri müzik bölümleri keman dersinde anlamlandırma stratejisinin kullanımı ve etkililik düzeyi. Yayınlanmamış doktora tezi, Gazi Üniversitesi, Ankara.

Anderson, J. R. (1995). Learning and Memory: An Integrated Approach. New York: Wiley.

Arends, R. I. (1997). Classroom instruction and management. The McGraw-Hill Companies, Inc.

Aşkar, P., \& Akkoyunlu, B. (1993). Kolb öğrenme stili envanteri. Eğitim ve Bilim, 87(17), 37-47.

Bar-Tal, T., \& Bar-Zahor, Y. (1977). The relationship between perception of locus of control and academic achievement. Contemporary Educational Psychology, 2, 181-199.

Bulut, S. (2006). İlköğretim II. kademe öğrencilerinin matematik dersinde kullandıkları öğrenme stratejileri ve başarı güdüleri. Yayımlanmamış yüksek lisans tezi, Trakya Üniversitesi, Edirne.

Çağıltay, N. E., \& Tokdemir, G. (2004, Mayıs). Mühendislik eğitiminde öğrenme stillerinin rolü. Paper presented at the I. Ulusal Mühendislik Kongresi, İzmir.

Cassidy, S., \& Eachus, P. (2000). Learning style, academic belief systems, self-report student proficiency and academic achievement in higher education. Educational Physicology, 20(3), 307-322. http://dx.doi.org/10.1080/713663740

Cebesoy, B. Ü. (2009). Fen eğitiminde anlamlandırma ve örgütleme stratejileri kullanımının öğrencilerin akademik başarı tutum ve kavram öğrenmelerine etkisi. Yayınlanmamış yüksek lisans tezi, Marmara Üniversitesi, Istanbul.

Dağ, İ. (1991). Rotter'in İç-Dış Kontrol Odağı Ölçeği (RIDKOÖ)'nin üniversite öğrencileri için güvenirliği ve geçerliliği. Psikoloji Dergisi, 26, 10-16.

Damavandi, A. J., Mahyuddin, R., Elias, H., Daud, S., \& Shabani, J. (2011). Academic Achievement of Students with Different Learning Styles. International Journal of Psychological Studies, 3(2), 186-192. http://dx.doi.org/10.5539/ijps.v3n2p186

Dunn, K., \& Dunn, R. (1993). Teaching secondary students through their individual learning styles practical approaches for grades (pp. 7-12). Massachusetts: Allyn and Bacon.

Fakeye, D. O. (2011). Locus Of Control As A Correlate Of Achievement In English As A Second Language In Ibadan. The Journal Of International Social Research, 4(17), 546-552. Retrieved from http://www.sosyalarastirmalar.com/cilt4/sayi17pdf/5egitim/fakeye_david.pdf

Felder, R. M., \& Brent, R. (2005). Understanding student differences. Journal of Engineering Education, 94(1), 57-72. Retrieved from http://eprints.me.psu.ac.th/ILS/info/Understanding_Differences.pdf

Gagnè, R. M. (1988). Principles of instructional design. Chicago: Halt, Rinehart and Winston.

Güven, M. (2004). Öğrenme stilleri ile öğrenme stratejileri arasındaki ilişki. Yayınlanmamış doktora tezi, Anadolu Üniversitesi, Eskişehir. 
Güven, M. (2008). Development of learning strategies scale: Study of validation and reliability. World Applied Sciences Journal, 4(1), 31-36. Retrieved from http://idosi.org/wasj/wasj4(1)/5.pdf

Halaçoğlu, M. (1999). The effect of cognitive styles on learner prefences. Yayımlanmamış yüksek lisans tezi, Çukurova Üniversitesi, Adana.

Haşlaman, T., \& Aşkar, P. (2007). Programlama dersi ile ilgili öz düzenleyici öğrenme stratejileri ve başarı arasındaki ilişkinin incelenmesi. Hacettepe Üniversitesi Eğitim Fakültesi Dergisi, 32, 110-122. Retrieved from

http://uvt.ulakbim.gov.tr/uvt/index.php?cwid=9\&vtadi=TPRJ\%2CTTAR\%2CTTIP\%2CTMUH\%2CTSOS

$\% 2$ CTHUK\& $=$ google $\&$ ano=76846_fe70a74cfa093d971b487e0ee6032bef

Jonassen, H. D., \& Grobowski, B. L. (1999). Handbook of individual differences, learning and instruction. USA: Lawrance Erlbaum Associates.

Kaplan, E. J., \& Kies, D. A. (1995). Teaching styles and learning styles. Journal of Instructional Psychology, 22(1), 29-34.

Karakış, Ö. (2006). Bazı yükseköğrenim kurumlarında farklı öğrenme stillerine sahip olan ögrencilerin genel ögrenme stratejilerini kullanma düzeyleri. Yayınlanmamış yüksek lisans tezi, Abant İzzet Baysal Üniversitesi, Bolu.

Karasar, N. (1998). Bilimsel araştırma yöntemi. Ankara: Nobel Yayın.

Kaya, D. (1995). The relationship between language learning strategy choice and academic success and factors related to learning strategy choice of efl undergraduate students in a turkish university. Yayımlanmamis yüksek lisans tezi, Bilkent Üniversitesi, Ankara.

Keane, M. (1993). Prefered learning styles and study strategies in a linguistically diverse baccalaurate nursing student population. The Journal of Nursing Education, 32(5), 214-221. Retrieved from http://0-search.proquest.com.seyhan.library.boun.edu.tr/docview/1026709415

Kolb, A. Y. (2005). The Kolb Learning Style Inventory, Version 3.1. Technical Specifications. Experience Based Learning Systems, Inc. HaysGroup.

Kolb, D. A. (1984). Experiential learning: Experience as the source of learning and development. New Jersey: Prentice Hall, Inc.. Engle wood Cliffs.

Lefcourt, H. M. (1992). Durability and impact of the locus of control construct. Psychological Bulletin, 112(3), 411-414. http://dx.doi.org /10.1037/0033-2909.112.3.411

Liu, M., \& Reed. M. W. (1994). The relationship between the learning strategies and learning styles in hypermadia environment. Computers in Human Behavior, 10(4), 419-434. http://dx.doi.org/10.1016/0747-5632(94)90038-8

Mayer, R. E. (1987). Educational psychology: A cognitive approach. USA: Little, Brown and Company Limited.

McCarthy, B. (1990). Using the 4MAT system to bring learning styles to schools. Educational Leadership, 48(32), 31-37. Retrieved from http://0-search.proquest.com.seyhan.library.boun.edu.tr/docview/224868412

Murray-Harvey, R. (1994). Learning styles and approaches to learning: Distinguishing between concepts and instruments. British Journal of Educational Psychology, 64, 373-388. http://dx.doi.org /10.1111/j.2044-8279.1994.tb01110.x

Nelson E. S., \& Mathı K. E. (1995). The Relationships Among College Students' Locus Of Control, Learning Styles, And Self-Prediction Of Grades Education Research And Perspectives. Education research and perspectives, 22(2), 110-117. Retrieved from $\mathrm{http} / / /$ cat.inist.fr/?aModele $=$ afficheN\&cpsidt $=2867133$

Nisbet J., \& Shucssmith, J. (1986). Learning strategies. London: Routledge and Kegan Paul.

Ocak, G., \& Yamaç, A. (2011). Öğrenme stratejileri, denetim odağı ve akademik başarı arasındaki ilişkilerin yapısal eşitlik modeli ile incelenmesi. Uludağ Üniversitesi Eğitim Fakültesi Dergisi, 24(2), 467-486. Retrieved from http://home.uludag.edu.tr/users/ucmaz/PDF/egitim/htmpdf/2011-24(2)/M10.pdf

Öngen, D. (2003). Denetim odağı ölçeğinin geçerlik ve güvenirlik çalışması. Kuram ve Uygulamada Eğitim Yönetimi, 35, 436-447.

Orhan, F. (2008). Self-regulation strategies used in a practicum course: A study of motivation and teaching self-efficacy. Hacettepe Üniversitesi Eğitim Fakültesi Dergisi, 35, 251-262. Retrieved from http://www.efdergi.hacettepe.edu.tr/200835FEZA\%20ORHAN.pdf 
Oxford, R., \& Ehrman, M. E. (1995). Adults language learning in a intensive foreign language program in the united states. System, 23(3), 359-386. http://dx.doi.org/10.1016/0346-251X(95)00023-D

Oxford, R., Oh Young, P., Sukero, I., \& Malenna, S. (1993). Learning a language by satellite television: What influences student achievement. System, 21(1), 31-48. http://dx.doi.org/10.1016/0346-251X(93)90005-2

Özer, B. (1998). Öğrenmeyi öğretme. Eğitim bilimlerinde yenilikler. In Ayhan, H. (Ed.), İlköğretim öğretmenliği lisans tamamlama programı. Eskişehir: Anadolu Üniversitesi Yayınları, No: 1016.

Öztürk, H. H. (1995). Genel öğrenme stratejilerinin ögrenciler tarafindan kullanılma durumları. Yayımlanmamış doktora tezi, Gazi Üniversitesi, Ankara.

Sadler-Smith, E. (1997). Learning Style: Frameworks and Instruments. Educational Psychology, 17(1-2), 51-64. http://dx.doi.org/10.1080/0144341970170103

Schunk, D. H. (2009). Öğrenme Teorileri Eğitimsel Bir Baklşla (Çev: Muzaffer Şahin). Ankara: Nobel Yayın Dağıtım.

Schunk, D. H., \& Zimmerman, B. J. (2003). Self-regulation and learning. Handbook of psychology, 7, 59-79.

Seigler, R. S. (1991). Strategy choice and strategy discovery. Learning and Instruction, 1, 89-102. http://dx.doi.org/10.1016/0959-4752(91)90020-9

Senemoğlu, N. (2010). Gelişim öğrenme ve öğretim kuramdan uygulamaya (16. Baskı). Ankara: Pegem Akademi Yayıncilik.

Şimşek, A. (2004). Ĕgitimde bireysel farklllıklar. Ankara: Nobel Yay.

Sünbül, A. M. (1998). Öğrenme stratejilerinin ögrencilerin erişi ve tutumlarına etkisi. Yayımlanmamış doktora tezi, Hacettepe Üniversitesi, Ankara.

Swanson, Lee. (1980). Cognitive Style, Locus Of Control, And School Achievement In Learning Disabled Female. $\begin{array}{lllll}\text { Journal Of } & \text { Clinical } & \text { Psychology, } & 36(4), & 964-967,\end{array}$ http://dx.doi.org/10.1002/1097-4679(198010)36:4<964::AID-JCLP2270360425>3.0.CO;2-6

Tinajero, C., \& Paramo, M. F. (1998). Field depence-independence and stratecig learning. International Journal of Educational Research, 29(3), 251-262. http://dx.doi.org/10.1016/S0883-0355(98)00029-9

Watkins, C., Carnell, E., Lodge, C., Wagner, P., \& Whalley, C. (2000). Learning about learning. London: Routledge Falmer.

Weinstein, C. E., \& Mayer, R. E. (1986). The teaching of learning strategies. In M. C.Wittrock (Ed.), Handbook of research on teaching. New York: Macmillan.

Wittrock, M. C. (1986). Students' thought processes. In M. C.Wittrock (Ed.), Handbook of research on teaching. New York: Macmillan.

Yeşilyaprak, B. (2004). Denetim odağı. In Y. Kuzgun, \& D. Deryakulu (Eds.), Eğitimde bireysel farklllıklar. Ankara: Nobel Yayınları.

Zimmerman, B. J. (1990). Self-regulated learning and academic achievement: An overview. Educational Psychologist, 25(1), 3-17. http://dx.doi.org/10.1207/s15326985ep2501_2 